\title{
Predictors of critical care nurses' intention to leave the unit, the hospital, and the nursing profession
}

\author{
Claudio Giovanni Cortese
}

Department of Psychology, University of Torino, Torino, Italy

Email: claudio.cortese@unito.it

Received 12 September 2012; revised 18 October 2012; accepted 30 October 2012

\begin{abstract}
Nursing turnover and shortage are acknowledged as worldwide issues: understanding the factors that foster nurses' intention to leave (ITL) is essential in retaining them. The present study aims at providing insight into the factors influencing critical care and intensive care nurses' ITL the unit, the hospital, and the nursing profession. The study was conducted in two hospitals, by a questionnaire administered to all nurses employed in critical and intensive care units. 512 questionnaires $(89.4 \%)$ were returned. Results revealed that a low job satisfaction (JS) for interaction with physicians and nurses, seniority $\geq 20$ years, and working in Emergency are related to higher ITL the unit. Low JS for work organization policies, seniority $\geq 11$ years, working in a private hospital, and higher educational level are related to higher levels of ITL the hospital. Low JS for professional status, for pay, and for work organization policies, age $\geq 40$ years, part-time schedule are related to higher ITL the nursing profession. The research permitted detection of various predictors of different kinds of ITL, enhancing the importance of regular monitoring of ITL. In order to limit ITL, it would be important to work on the relationship with physicians and colleagues, work demands, organizational policies, and acknowledgement of competence.
\end{abstract}

Keywords: Critical Care; Intensive Care; Intention to Leave; Nurse Management; Job Satisfaction

\section{INTRODUCTION}

In the last decade nursing shortage has been acknowledged as a worldwide issue. The majority of Organisation for Economic Co-operation and Development (OECD) countries report nursing shortages, and in these countries unemployment of nurses appears to be marginal [1-3]. According to [4], the healthcare workforce crisis has been having an impact on many countries' ability to fight disease and improve health. Among the causes of these situations are increasing demands of health services, ageing of the population, a diminishing workforce, lack of training courses and nurses abandoning the profession $[1,5,6]$.

As for each single health institution, the problem of organizational leave is added, leading to personnel substitutions and an increase in costs. In short, lack of nurses and nurse turnover represent a major problem for nursing and health-care in terms of the ability to care for patients [7], the quality of care [8,9] and costs [10].

When nurses leave, the quality of nursing care may decline due to the loss of expertise. In addition, novice nurses may not have the same commitment to the organization or the ability, intuition, and confidence as an expert nurse [6]. Moreover, the organizations that lose workers inevitably have to face costs. [11] estimated the total turnover costs of one nurse to range from $\$ 62,000$ to $\$ 67,000$, depending on the service line, including the costs of recruitment, selection, orientation, training, and productivity loss. It is also worthy to note that a request to change the unit in which one works, while remaining within the same organization, results in costs, linked to the management of demands, to the training necessary for those who have changed their working unit and to diminished productivity over the period of new organizational socialization.

$[12,13]$ highlighted how nursing shortages have not been institution-wide but concentrated in specialty care areas, in particular intensive care units and operating rooms. Similarly, a Study by [6] indicates that the specialty areas, especially intensive care units, had the highest nurse turnover rate (26\%), and, in [14]'s words "shortage is most evident in critical care, emergency services, and perioperative care" (p. 348). Such a problem is aggravated by the fact that nurses working in these units hold specialized knowledge, skills, and experience necessary to safely deal with the challenges of meeting the complex needs of critically-ill patients.

Research conducted in Italy has confirmed that the nursing shortage is a current problem. All of the above- 
mentioned causes are also present in Italy: it is "estimated to be a structural shortage of over 70,000 nurses; insufficient numbers graduate from nursing schools and the replacement of the nursing workforce is not ensured" $[15$, p. 243].

In this sense, [16] mentioned "Italy's acute nursing shortage" and Italian Nurses Federation (IPASVI) estimated a number of 158,000 nurses required to bring Italy in line with the average OECD member countries [17]. In addition, a high turnover rate is added: studies conducted in the Emilia Romagna region on a population of 23,456 nurses on duty starting from 2004 has showed how the probability of leaving was $50 \%$ at only 3 and a half years after hiring, and $60 \%$ at 5 years [18].

A solution to the nursing shortage consists of employing foreign personnel. For example, more than 34,000 foreign nurses are working in Italy at present, around $10 \%$ of its total membership. In general, all Western European countries show a growing tendency to employ foreign nurses, mainly from Eastern Europe, Africa and Latin America [19]. A second solution, though very onerous, could be to increase education and training opportunities. Therefore, in order to contain public expenses as well, many authors suggest $[20,21]$ concentrating efforts in order to reduce organizational leave (i.e. leaving an organization for another one or becoming a freelancer) or professional leave (i.e. leaving to take up some other profession or to stop working altogether). Understanding the psychological process leading to the decision to leave the unit, the hospital and the nursing profession, detecting factors intervening in this process, is therefore crucial. The study of these factors appears unavoidable both for planning retention policies for employed personnel and for attracting personnel available in the labour market [22]. The urgency is particularly noticeable in the Italian context, which has been object of a limited number of studies up until now [23].

\subsection{Intention to Leave}

The nurse turnover has been described as a withdrawal process or as chain reaction: nurses may first leave their unit, then the hospital and finally the profession [24,25].

Moreover, each of these steps is the result of a choice process originating from the intention to leave (ITL): although intention is not always followed by action, action is always preceded by intention that can manifest itself some time before (from two-three months to twothree years) actually leaving (the unit, the hospital, or the nursing profession) or the final decision to stay on [26, 27]. In this lapse of time, [28] maintains that individuals keep on working in their positions despite the fact that they feel "on the border" with the outside. For this reason ITL is presently regarded as "the most direct and immediate antecedent of overt turnover behaviour" [29, p.
249].

In addition, [28] continues, different predictors can be found behind ITL. Among these, work satisfaction plays a lead role: [30], for example, found that nurses who reported overall dissatisfaction with their jobs had a $65 \%$ higher probability of intending to leave than satisfied nurses. Many other studies have highlighted how personal experiences characterized by dissatisfaction relative to various aspects, such as the nature of the activities performed, work load, career opportunities, autonomy, training opportunities, fairness in evaluation systems, financial rewards, benefits, physical characteristics of working environment are linked to higher ITL $[6,8,20,25$, 29,31-36]. Many studies have consistently reported positive relationships between nurses' intention to stay on and perception of job satisfaction, including satisfaction with pay and benefits [25,37-39], scheduling [40], autonomy and responsibility [41], and professional development opportunities [26,42,43].

Along with work satisfaction, other variables can influence ITL: personal characteristics such as gender [26, 37], age [26,31,37,44-46], education [40], professional qualification $[26,37,47]$, years of experience $[45,48,49]$; context and organizational factors, such as type of organization, type of units, clearness in work processes and roles [29,50], presence of threads of aggression risks and of biological risks [51]; psychosocial factors. Particularly relevant among the latter are: relationships with colleagues [20,48,52-54], managers' style [51,55], work-family conflict and work-life conflict [42,47,56-61]. Further predictors of ITL investigated by scholars are work-related stress $[62,63]$ and burnout $[26,47]$.

\subsection{Job Satisfaction}

Job satisfaction (JS) was defined by [64] as "the extent to which people like (satisfaction) or dislike (dissatisfaction) their jobs" (p. 2). Different dimensions or facets of satisfaction have also been described, e.g. nature of the work, job conditions, supervision, co-workers, career, training opportunities, pay and benefits $[65,66]$. To date, no complete classification of the factors of JS as perceived by nurses exists. Various questionnaires cover various factors but there is no consistency between factors covered by questionnaires and those highlighted through qualitative studies [67].

Relevance of JS, attested by the great number of studies employing it as an independent variable, lies not only on its relation to ITL, but to many other variables as well. It is important to mention here that JS is related to absenteeism, work performance, patient-satisfaction and service quality: all of these are elements that, together, can compromise the overall results of an organization [8,35,68-74]. In addition, JS appears to be an antecedent to life satisfaction [75]. 
According to the literature, although personality factors can influence an employee's work satisfaction [76, $77]$, the characteristics of the organization and of work activities have a crucial impact on JS [44,64,78-83]. Therefore, a person's JS can change throughout his/her professional career depending on the different contexts, departments, supervisors, co-workers, duties, etc. progressively encountered $[83,84]$. The characteristics of the organization that can influence JS are, among others, role ambiguity, work load, communication, recognition, routinization and care setting $[85,86]$. The unbalance between work and personal life is associated with a lower JS as well [87-89].

\subsection{Study Objective}

The OECD report on nursing shortages concluded that policies designed to reduce the flow of nurses out of the workforce are still relatively underdeveloped in many OECD countries [2]. Understanding the reasons why nurses consider leaving their unit, hospital or profession is essential in order to keep them in nursing. Moreover, if the nursing community gained a better understanding of the reasons why nurses have developed an ITL, there might be more possibilities of attracting leavers back [1].

The aim of this study was to identify the factors influencing critical care and intensive care nurses' ITL while taking into account personal characteristics, context characteristics and JS factors. As literature suggests [24,25], three different kinds of ITL have been determined: ITL the unit, ITL the hospital, ITL the nursing profession.

Even if it represents a research field essential to steer policies acting against turnover and professional leave, few studies have been conducted within the Italian context as of yet. Among these, the Nurses' Early Exit (NEXT) Study [61] highlighted how Italian nurses show a desire to leave their profession more frequently compared to those in other European countries; [23] Study emphasised the role of supervising and organizational supports in the relationship between nurses' perceptions of care adequacy, JS, and turnover intention; [33] Study highlighted that the tendency to leave the profession was associated with job dissatisfaction, burnout symptoms and the labour market situation; [87] Study stressed the role of work-life conflict as an antecedent of JS, moderated by support on the part of colleagues and supervisors. It is important to note that no research carried out in Italy as of yet has detected the ITL the unit, ITL the hospital, and the ITL the nursing profession simultaneously.

\section{METHOD}

\subsection{Subjects}

The present study was conducted in two large hospitals
- one public, the other private - in a big city in Northern Italy. The research instrument was a self-completed structured questionnaire, which was administered to all nurses employed in the critical care and intensive care units of both hospitals.

Upon approval of the hospitals' Boards of Directors, nurse coordinators of each unit were asked for authorization to administer the questionnaire to nurses. All nurse coordinators consented and the questionnaire was administered in 12 critical and intensive care units (six in the public hospital and six in the private one). Each nurse received the questionnaire from his/her coordinator with a letter by the head of the study (explaining the research aim, underlying voluntary participation and ensuring anonymous collection and processing of data) and a blank envelope to return the questionnaire in. The questionnaires were returned into a box located in the unit meeting room. 573 questionnaires were distributed, of which 512 (89.4\% response rate) were returned completely filled-in (Table 1).

\subsection{Study Questionnaire}

The questionnaire consisted of four sections.

Personal characteristics: age $(\leq 29 ; 30$ - 39; 40 - 49; $\geq 50$ ), gender (woman; man), marital status (single; married or in cohabitation), educational level (degree or university master/specialization; diploma), role (nurse coordinator; nurse), work schedule (full-time; part-time), work experience ( $\leq 5 ; 6-10 ; 11-20 ; \geq 20$ years).

Context characteristics: hospital (public; private), type of unit (cardiology; emergency; medicine; obstetrics/neonatal; paediatrics; surgery).

$J S$ was detected through 44 items of Work Satisfaction Index section B [77, adapted by 67]. The items are measured on a 7-point Likert scale from 1 (strongly disagree) to 7 (strongly agree). The questionnaire includes seven factors: autonomy (9 items), professional status ( 7 items), pay (6 items), job requirements (6 items), work organization policies (6 items), interaction with physicians $(5$ items), interaction with nurses (5 items).

ITL was detected through 3 items placed at the end of the questionnaire which could be answered yes, no, don't know. The "don't know" answers have not been included in the study. These three items refer to the three ITL kinds described above: "Do you intend to change the unit where you work, remaining in the same hospital?"; "Do you intend to change the hospital where you work?"; "Do you intend to give up the nursing profession?" A similar question, on the same response scale, was used by [90] in a Study on ITL the nursing profession.

\subsection{Ethical Considerations}

The study was approved by the Board of Directors of the 
Table 1. Characteristics of the research sample.

\begin{tabular}{|c|c|c|c|}
\hline & & $\mathrm{n}$ & $\%$ \\
\hline \multirow{4}{*}{$\begin{array}{l}\text { Age (years) } \\
(\mathrm{N}=511)\end{array}$} & $\leq 29$ & 83 & $16.2 \%$ \\
\hline & $30-39$ & 185 & $36.2 \%$ \\
\hline & $40-49$ & 162 & $31.7 \%$ \\
\hline & $\geq 50$ & 81 & $15.8 \%$ \\
\hline \multirow{2}{*}{$\begin{array}{c}\text { Gender } \\
(\mathrm{N}=509)\end{array}$} & Women & 415 & $81.5 \%$ \\
\hline & Men & 94 & $18.5 \%$ \\
\hline \multirow{2}{*}{$\begin{array}{l}\text { Marital status } \\
(\mathrm{N}=506)\end{array}$} & Single & 211 & $41.7 \%$ \\
\hline & $\begin{array}{l}\text { Married/in } \\
\text { cohabitation }\end{array}$ & 295 & $58.3 \%$ \\
\hline \multirow{2}{*}{$\begin{array}{l}\text { Work schedule } \\
\qquad(\mathrm{N}=510)\end{array}$} & Full-time & 460 & $90.2 \%$ \\
\hline & Part-time & 50 & $9.8 \%$ \\
\hline \multirow{2}{*}{$\begin{array}{l}\text { Educational level } \\
\qquad(\mathrm{N}=509)\end{array}$} & $\begin{array}{l}\text { Degree/Master/ } \\
\text { Specialization }\end{array}$ & 140 & $27.5 \%$ \\
\hline & Diploma & 369 & $72.5 \%$ \\
\hline \multirow{3}{*}{$\begin{array}{c}\text { Role } \\
(\mathrm{N}=511)\end{array}$} & Nurses Coordinator & 43 & $8.4 \%$ \\
\hline & Nurse & 468 & $91.6 \%$ \\
\hline & $\leq 5$ & 66 & $12.9 \%$ \\
\hline \multirow{3}{*}{$\begin{array}{l}\text { Work experience } \\
\quad \text { (years) } \\
(\mathrm{N}=511)\end{array}$} & $6-10$ & 125 & $24.5 \%$ \\
\hline & $11-20$ & 206 & $40.3 \%$ \\
\hline & $\geq 20$ & 114 & $22.3 \%$ \\
\hline \multirow{2}{*}{$\begin{array}{l}\text { Hospital } \\
(\mathrm{N}=512)\end{array}$} & Public & 305 & $59.6 \%$ \\
\hline & Private & 207 & $40.4 \%$ \\
\hline \multirow{6}{*}{$\begin{array}{c}\text { Unit } \\
(\mathrm{N}=509)\end{array}$} & Cardiology & 81 & $15.9 \%$ \\
\hline & Emergency & 76 & $14.9 \%$ \\
\hline & Medicine & 104 & $20.4 \%$ \\
\hline & $\begin{array}{l}\text { Obstetrics and } \\
\text { Neonatal }\end{array}$ & 46 & $9.0 \%$ \\
\hline & Paediatrics & 51 & $10.0 \%$ \\
\hline & Surgery & 151 & $29.7 \%$ \\
\hline
\end{tabular}

two hospitals. Participant nurses were informed by a letter about the voluntary nature of participation and confidentiality in handling the data. They were not required to sign a consent form: questionnaire return implied consent.

\subsection{Data Analysis}

The data were analysed using PASW18. First, a descriptive statistical analysis of the quantitative data was conducted. Next, Cronbach's alpha coefficients were used to examine internal coherence and reliability of each sub- scale of Work Satisfaction Index. Results obtained were satisfactory for all the scales (see Table 2).

Univariate analysis was then used to examine factors (personal characteristics, context characteristics and JS factors) associated with ITL. Finally, a multiple logistic regression model (forward stepwise Ward's method) was used to identify which factors can predict ITL, with the level of significance set at $p<0.05$. The fit of the logistic model was assessed by using the goodness-of-fit test according to [91].

In these two latest stages, with reference to the JS scale, answers have been classified in three categories: unsatisfied (grades 1 - 3), satisfied (grades 5 - 7) and "in the middle" (grade 4). With reference to ITL, "don't know" answers were not used in data analysis. Therefore, the number of cases amounted to 409 for ITL the unit, 361 for ITL the hospital and 425 for ITL the nursing profession.

\section{RESULTS}

Tables 2 and $\mathbf{3}$ show the results obtained from questions relative to JS and ITL.

As for JS, a higher satisfaction was registered for the aspects regarding interaction with nurses, professional status, and autonomy; on the other hand, a perception of dissatisfaction was registered in regards to pay and job requirements.

With reference to ITL, $41.8 \%$ of respondents reported their intention to leave the unit they work in, though re-

Table 2. Job satisfaction (JS) factors $(\mathrm{N}=512)$.

\begin{tabular}{cccc}
\hline & $\begin{array}{c}\text { Mean } \\
\text { (subscale) }\end{array}$ & $\begin{array}{c}\text { Mean } \\
(1-7)\end{array}$ & $\begin{array}{c}\text { Cronbach's } \\
\text { alpha }\end{array}$ \\
\hline $\begin{array}{ccc}\text { Autonomy (9 item) } \\
\text { Professional status (7) }\end{array}$ & 42.66 & 4.74 & 0.90 \\
Pay (6) & 13.44 & 2.24 & 0.87 \\
Job requirements (6) & 17.88 & 2.98 & 0.83 \\
Work organization policies (6) & 19.80 & 3.30 & 0.80 \\
Interaction with physicians (5) & 18.70 & 3.74 & 0.88 \\
Interaction with nurses (5) & 24.95 & 4.99 & 0.89 \\
\hline
\end{tabular}

Table 3. Intention to leave (ITL) $(\mathrm{N}=512)$.

\begin{tabular}{ccccc}
\hline ITL & $\begin{array}{c}\text { Yes } \\
\mathrm{n}(\%)\end{array}$ & $\begin{array}{c}\text { No } \\
\mathrm{n}(\%)\end{array}$ & $\begin{array}{c}\text { Don't } \\
\text { know }\end{array}$ & Total \\
\hline ITL the unit & 214 & 195 & 103 & 512 \\
& $(41.8 \%)$ & $(38.1 \%)$ & $(20.1 \%)$ & $(100 \%)$ \\
ITL the hospital & 112 & 249 & 151 & 512 \\
& $(21.9 \%)$ & $(48.6 \%)$ & $(29.5 \%)$ & $(100 \%)$ \\
$\begin{array}{c}\text { ITL the nursing } \\
\text { profession }\end{array}$ & 75 & 350 & 87 & 512 \\
\hline
\end{tabular}


maining in the same hospital; $21.9 \%$ reported an intention to change the hospital and $14.6 \%$ to give up the nursing profession altogether.

Tables 4 to 6 describe the course of ITL as a function of personal and context characteristics.

As for ITL the unit (Table 4), significant personal characteristics were: age, work experience, and educational level. More precisely, among individuals with lower age and shorter work experience, as with those with a higher educational level, the ratio of nurses in- tending to leave was higher. With regards to context characteristics, analysis per working unit showed a significant relation: the highest percentage was reported for Emergency Units.

As for ITL the hospital (Table 5), the most significant personal characteristics were age, gender, work schedule, educational level, role, and work experience. With regards to context characteristics, individuals employed in the private hospital reported a higher ITL compared to their colleagues working in the public one.

Table 4. ITL the unit by personal and context characteristic.

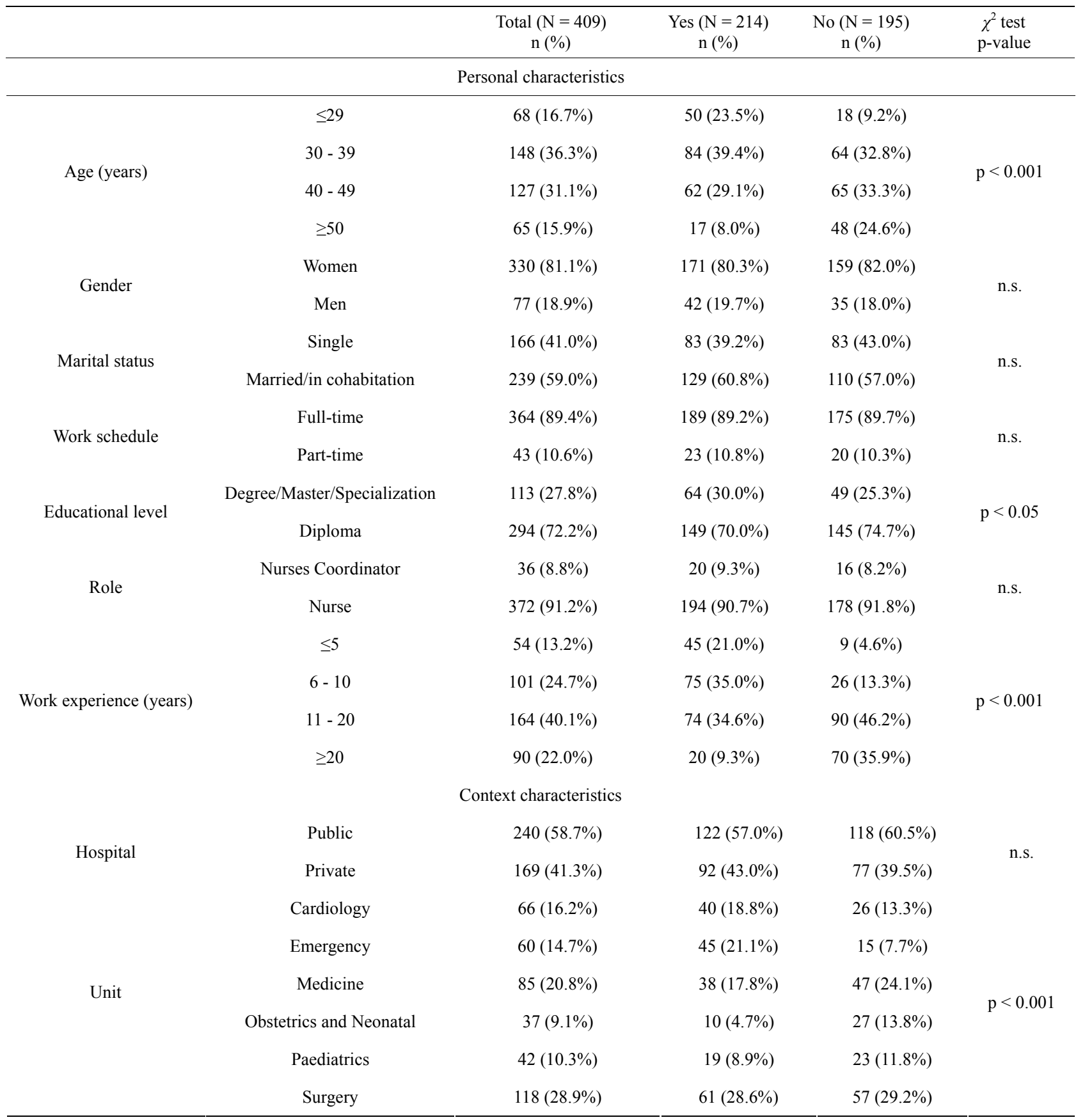


Table 5. ITL the hospital by personal and context characteristic.

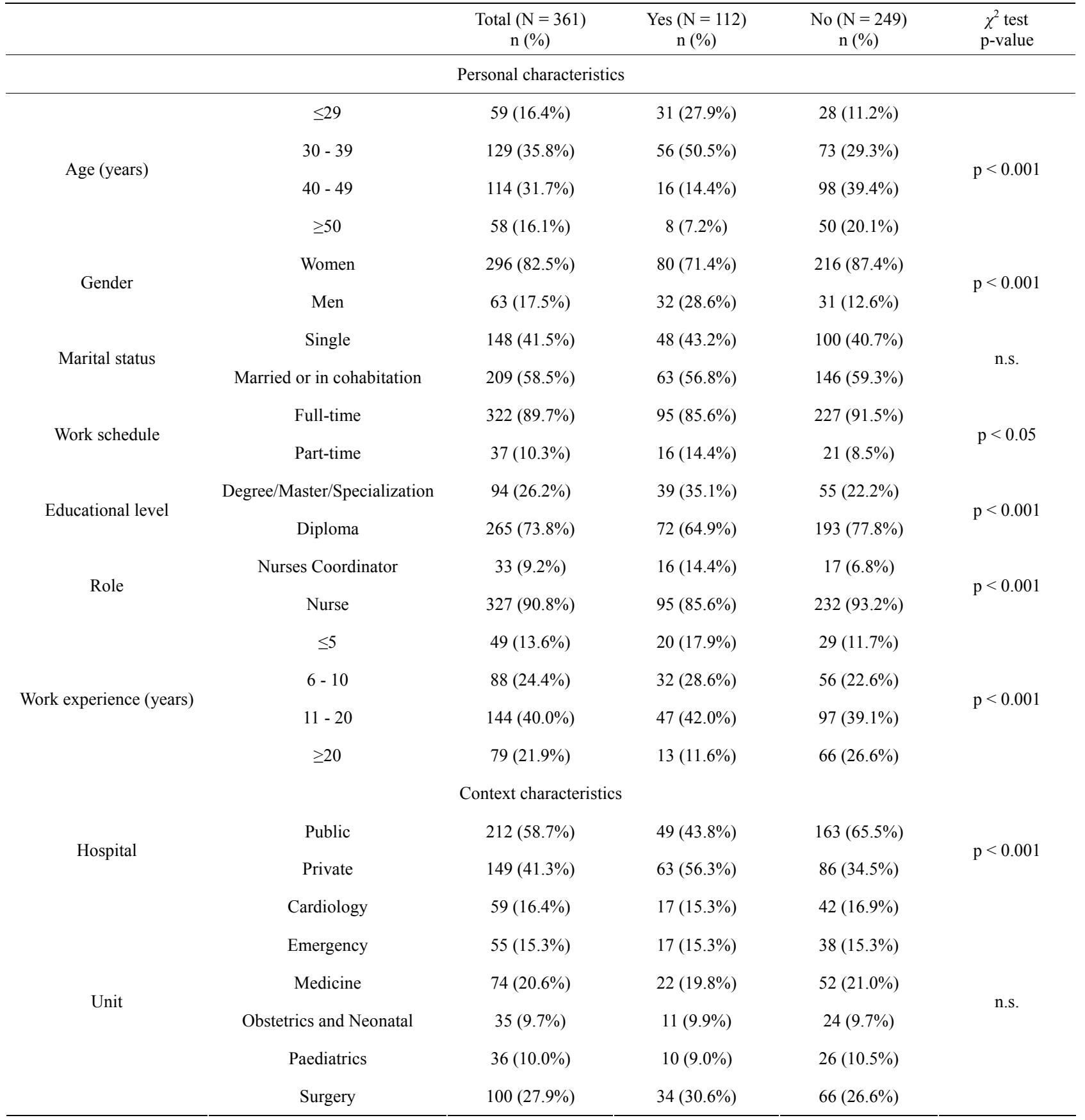

As for ITL the nursing profession (Table 6), significant personal characteristics were: age, work schedule, role, and work experience. With regards to context characteristics, there was a significant difference between public and private hospital, but not between units.

Tables 7 to 9 show the course of ITL as a function of JS ratings.

In regards to ITL the unit (Table 7), significant differences were registered in function of JS ratings for job requirements, interaction with physicians and interaction with nurses.

As for ITL the hospital (Table 8), significant differences were those concerning JS rating relative to autonomy, job requirements, work organization policies and interaction with nurses.

As far as ITL the nursing profession was concerned (Table 9), significant differences emerged from all JS factors ratings except interaction with nurses.

Lastly, Tables 10 to $\mathbf{1 2}$ show the results obtained by the multiple logistic regression model used to identify 
Table 6. ITL the nursing profession by personal and context characteristic.

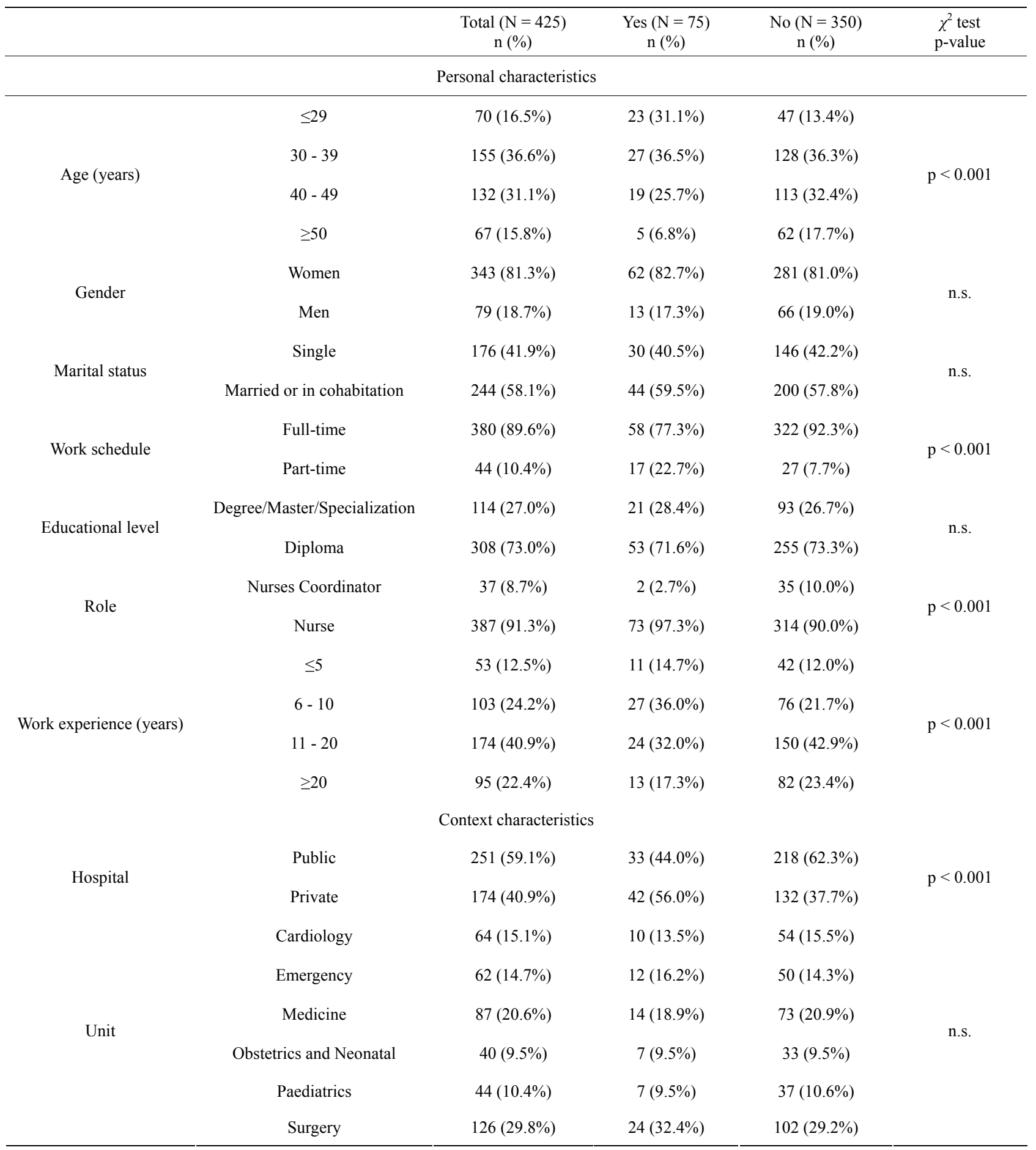

which factors can predict ITL.

As for ITL the unit (Table 10), the results showed that a low JS for interaction with physicians and for interacttion with nurses, work experience $\leq 5$ years and working in the emergency unit were related to a higher ITL.

As for ITL the hospital (Table 11), the results showed that low JS for job requirements and for work organiza- tion policies, working in a private hospital, educational level equal to a degree or university master's/specialization, and work experience $\leq 5$ years were related to a higher level of ITL.

Concerning ITL the nursing profession (Table 12), the results showed that low JS for professional status, for pay and for work organization policies, age $\leq 29$ years, 
Table 7. ITL the unit by JS factors.

\begin{tabular}{|c|c|c|c|c|c|}
\hline \multicolumn{2}{|c|}{ JS Factors } & \multirow{2}{*}{$\begin{array}{c}\text { Total }(\mathrm{N}=409) \\
\mathrm{n}(\%)\end{array}$} & \multirow{2}{*}{$\begin{array}{c}\text { Yes }(\mathrm{N}=214) \\
\mathrm{n}(\%)\end{array}$} & \multirow{2}{*}{$\begin{array}{c}\text { No }(\mathrm{N}=195) \\
\mathrm{n}(\%) \\
45(23.1 \%)\end{array}$} & \multirow[t]{2}{*}{$\begin{array}{l}\chi^{2} \text { test } \\
\text { p-value }\end{array}$} \\
\hline & Unsatisfied & & & & \\
\hline \multirow[t]{3}{*}{ Autonomy } & Satisfied & $243(59.4 \%)$ & $125(58.4 \%)$ & $118(60.5 \%)$ & n.s. \\
\hline & In the middle & $66(16.1 \%)$ & $34(15.9 \%)$ & $32(16.4 \%)$ & \\
\hline & Unsatisfied & $89(21.8 \%)$ & $47(21.8 \%)$ & $42(21.5 \%)$ & \\
\hline \multirow[t]{3}{*}{ Professional status } & Satisfied & $272(66.5 \%)$ & $139(65.0 \%)$ & $133(68.2 \%)$ & n.s. \\
\hline & In the middle & $48(11.7 \%)$ & $28(13.1 \%)$ & $20(10.3 \%)$ & \\
\hline & Unsatisfied & $325(79.5 \%)$ & $171(79.9 \%)$ & $154(79.0 \%)$ & \\
\hline \multirow[t]{3}{*}{ Pay } & Satisfied & $47(11.5 \%)$ & $25(11.7 \%)$ & $22(11.3 \%)$ & n.s. \\
\hline & In the middle & $37(9.0 \%)$ & $18(8.4 \%)$ & $19(9.7 \%)$ & \\
\hline & Unsatisfied & $263(64.3 \%)$ & $146(68.2 \%)$ & $117(60.0 \%)$ & \\
\hline \multirow[t]{3}{*}{ Job requirements } & Satisfied & $81(19.8 \%)$ & $39(18.2 \%)$ & $42(21.5 \%)$ & $\mathrm{p}<0.01$ \\
\hline & In the middle & $65(15.9 \%)$ & $29(13.6 \%)$ & $36(18.5 \%)$ & \\
\hline & Unsatisfied & $206(50.4 \%)$ & $110(51.4 \%)$ & $96(49.2 \%)$ & \\
\hline \multirow[t]{3}{*}{$\begin{array}{c}\text { Work organization } \\
\text { policies }\end{array}$} & Satisfied & $142(34.7 \%)$ & $73(34.1 \%)$ & $69(35.4 \%)$ & n.s. \\
\hline & In the middle & $61(14.9 \%)$ & $31(14.5 \%)$ & $30(15.4 \%)$ & \\
\hline & Unsatisfied & $187(45.7 \%)$ & $125(58.4 \%)$ & $62(31.8 \%)$ & \\
\hline \multirow[t]{3}{*}{$\begin{array}{l}\text { Interaction with } \\
\text { physicians }\end{array}$} & Satisfied & $142(34.7 \%)$ & $57(26.6 \%)$ & $85(43.6 \%)$ & $\mathrm{p}<0.001$ \\
\hline & In the middle & $80(19.6 \%)$ & $32(15.0 \%)$ & $48(24.6 \%)$ & \\
\hline & Unsatisfied & $82(20.0 \%)$ & $64(29.9 \%)$ & $18(9.2 \%)$ & \\
\hline \multirow[t]{2}{*}{ Interaction with nurses } & Satisfied & $258(63.1 \%)$ & $117(54.7 \%)$ & $141(72.3 \%)$ & $\mathrm{p}<0.001$ \\
\hline & In the middle & $69(16.9 \%)$ & $33(15.4 \%)$ & $36(18.5 \%)$ & \\
\hline
\end{tabular}

and part-time work schedule were related to a higher ITL.

As reported in the tables, all the models had a good fit under the [91] goodness-of-fit test.

\section{DISCUSSION}

With regards to JS, results prove to be in line with other research conducted in Italy [67,92-95].

The result relative to ITL the nursing profession appears to be consistent with what has emerged from previous research conducted in Italy as well: the NEXT Study, for instance, had found a percentage between $18.1 \%$ (in 2002/2003) and 20.7\% (in 2003/2004) of nurses that frequently consider leaving the nursing profession [26,59]. This result appears also to be consistent with the data obtained from studies conducted in critical and intensive care units in other countries: e.g., [12] had detected a percentage of $17 \%$ nurses with high ITL, while other studies reported percentages between $15 \%$ and $36 \%[96,97]$. As far as predictors of ITL the nursing profession are concerned, aspects relative to pay and work organization policies confirm what was already detected in the above mentioned NEXT Study in Italy.

Nevertheless, the present research made it possible detection of both predictors of ITL the unit and ITL the hospital, not yet investigated in Italy. Since ITL the nursing profession can start as a withdrawal process, in that nurses may first leave their unit, then the organization and finally leave the profession [24,25], knowing the predictors of the first steps proves to be important: if human resource management direction and nurse managers are able to stop this process, more nurses may be kept in the profession. Moreover, costs linked to an excessive number of internal changes and high turnover can be reduced.

In relation to predictors of ITL, this research made it possible a distinction between personal characteristics, context characteristics and JS factors.

As for personal characteristics, there is no variable re- 
Table 8. ITL the hospital by JS factors.

\begin{tabular}{|c|c|c|c|c|c|}
\hline \multicolumn{2}{|c|}{ JS Factors } & \multirow{2}{*}{$\begin{array}{c}\text { Total }(\mathrm{N}=361) \\
\mathrm{n}(\%) \\
89(24.7 \%)\end{array}$} & \multirow{2}{*}{$\begin{array}{c}\text { Yes }(\mathrm{N}=112) \\
\mathrm{n}(\%) \\
38(33.9 \%)\end{array}$} & \multirow{2}{*}{$\begin{array}{c}\text { No }(\mathrm{N}=249) \\
\mathrm{n}(\%) \\
51(20.5 \%)\end{array}$} & \multirow[t]{2}{*}{$\begin{array}{l}\chi^{2} \text { test } \\
\mathrm{p} \text {-value }\end{array}$} \\
\hline & Unsatisfied & & & & \\
\hline \multirow[t]{3}{*}{ Autonomy } & Satisfied & $214(59.3 \%)$ & $61(54.5 \%)$ & $153(61.4 \%)$ & $\mathrm{p}<0.001$ \\
\hline & In the middle & $58(16.1 \%)$ & $13(11.6 \%)$ & $45(18.1 \%)$ & \\
\hline & Unsatisfied & $79(21.9 \%)$ & $35(31.3 \%)$ & $44(17.7 \%)$ & \\
\hline \multirow[t]{3}{*}{ Professional status } & Satisfied & $239(66.2 \%)$ & $63(56.3 \%)$ & $176(70.7 \%)$ & n.s. \\
\hline & In the middle & $43(11.9 \%)$ & $14(12.5 \%)$ & $29(11.6 \%)$ & \\
\hline & Unsatisfied & $287(79.5 \%)$ & $90(80.4 \%)$ & $197(79.1 \%)$ & \\
\hline \multirow[t]{3}{*}{ Pay } & Satisfied & $42(11.6 \%)$ & $15(13.4 \%)$ & $27(10.8 \%)$ & n.s. \\
\hline & In the middle & $32(8.9 \%)$ & $7(6.3 \%)$ & $25(10.0 \%)$ & \\
\hline & Unsatisfied & $233(64.5 \%)$ & $83(74.1 \%)$ & $150(60.2 \%)$ & \\
\hline \multirow[t]{3}{*}{ Job requirements } & Satisfied & $71(19.7 \%)$ & $15(13.4 \%)$ & $56(22.5 \%)$ & $\mathrm{p}<0.001$ \\
\hline & In the middle & $57(15.8 \%)$ & $14(12.5 \%)$ & $43(17.3 \%)$ & \\
\hline & Unsatisfied & $183(50.7 \%)$ & $80(71.4 \%)$ & $103(41.4 \%)$ & \\
\hline \multirow[t]{3}{*}{$\begin{array}{l}\text { Work organization } \\
\text { policies }\end{array}$} & Satisfied & $125(34.6 \%)$ & $14(12.5 \%)$ & $111(44.6 \%)$ & $\mathrm{p}<0.001$ \\
\hline & In the middle & $53(14.7 \%)$ & $18(16.1 \%)$ & $35(14.1 \%)$ & \\
\hline & Unsatisfied & $165(45.7 \%)$ & $49(43.8 \%)$ & $116(46.6 \%)$ & \\
\hline \multirow[t]{3}{*}{$\begin{array}{l}\text { Interaction with } \\
\text { physicians }\end{array}$} & Satisfied & $125(34.6 \%)$ & $38(33.9 \%)$ & $87(34.9 \%)$ & n.s. \\
\hline & In the middle & $71(19.7 \%)$ & $25(22.3 \%)$ & $46(18.5 \%)$ & \\
\hline & Unsatisfied & $73(20.2 \%)$ & $26(23.2 \%)$ & $47(18.9 \%)$ & \\
\hline \multirow[t]{2}{*}{ Interaction with nurses } & Satisfied & $227(62.9 \%)$ & $65(58.0 \%)$ & $162(65.1 \%)$ & $\mathrm{p}<0.01$ \\
\hline & In the middle & $61(16.9 \%)$ & $21(18.8 \%)$ & $40(16.1 \%)$ & \\
\hline
\end{tabular}

lated to all three kinds of ITL taken into consideration. Nevertheless, it is worth noting how work experience shows a negative relation with both ITL the unit and ITL the hospital, whereas age is negatively related to ITL the nursing profession. Similarly to what was found by $[13$, $21,90]$, respondents with lower work experience or lower age report a higher ITL; in this sense, the characteristic of strong loyalty that [98] attribute to nurses born in the 1960s was confirmed in Italy. Educational level, on the contrary, is positively related to ITL the hospital. This result may be explained considering that in Italy nurses with a degree tend to be younger and have more chances to be re-collocated in another hospital, therefore they are more inclined to take job offers into consideration and to hypothesize transfers, while holders of a diploma only perceive a higher sense of working uncertainty outside their own context. Finally, work schedule, in accordance with $[12,13]$, is related to ITL the nursing profession. This result may be explained by taking into account that nurses applying for a part-time employment are often those perceiving a higher work-family conflict: when even this solution proves inadequate to solve their workfamily conflict, they would tend to opt for giving up the nursing profession [26,59].

As for the context characteristic, both are considered to influence ITL. On the one hand, as foreseeable, the kind of hospital influences ITL the hospital. On the other hand, the work unit influences ITL the unit: in particular, the unit with the highest ITL is the emergency unit. It is therefore necessary for job rotation programmes to be planned, so that requests of being transferred from an emergency unit after two-three years can be met [90]. This would not only make it possible to recover after exposure to a heavy work load but also to enrich professional competence given the opportunity to work in a new area of specialisation.

Regarding JS factors, ITL the unit is more influenced by personal relationships (with physicians and nurses). This result, consistent with [12], again with reference to critical and intensive care units, highlights the need to 
Table 9. ITL the nursing profession by JS factors.

\begin{tabular}{|c|c|c|c|c|c|}
\hline \multicolumn{2}{|c|}{ JS Factors } & \multirow{2}{*}{$\begin{array}{c}\text { Total }(\mathrm{N}=425) \\
\mathrm{n}(\%) \\
105(24.7 \%)\end{array}$} & \multirow{2}{*}{$\begin{array}{c}\text { Yes }(\mathrm{N}=75) \\
\mathrm{n}(\%) \\
22(29.3 \%)\end{array}$} & \multirow{2}{*}{$\begin{array}{c}\text { No }(\mathrm{N}=350) \\
\mathrm{n}(\%) \\
83(23.7 \%)\end{array}$} & \multirow[t]{2}{*}{$\begin{array}{c}\chi^{2} \text { test } \\
\text { p-value }\end{array}$} \\
\hline & Unsatisfied & & & & \\
\hline \multirow[t]{3}{*}{ Autonomy } & Satisfied & $252(59.3 \%)$ & $41(54.7 \%)$ & $211(60.3 \%)$ & $\mathrm{p}<0.01$ \\
\hline & In the middle & $68(16.0 \%)$ & $12(16.0 \%)$ & $56(16.0 \%)$ & \\
\hline & Unsatisfied & $93(21.9 \%)$ & $24(32.0 \%)$ & $69(19.7 \%)$ & \\
\hline \multirow[t]{3}{*}{ Professional status } & Satisfied & $282(66.4 \%)$ & $41(54.7 \%)$ & $241(68.9 \%)$ & $\mathrm{p}<0.001$ \\
\hline & In the middle & $50(11.8 \%)$ & $10(13.3 \%)$ & $40(11.4 \%)$ & \\
\hline & Unsatisfied & $338(79.5 \%)$ & $70(93.3 \%)$ & $268(76.6 \%)$ & \\
\hline \multirow[t]{3}{*}{ Pay } & Satisfied & $49(11.5 \%)$ & $4(5.3 \%)$ & $45(12.9 \%)$ & $\mathrm{p}<0.001$ \\
\hline & In the middle & $38(8.9 \%)$ & $1(1.3 \%)$ & $37(10.6 \%)$ & \\
\hline & Unsatisfied & $274(64.5 \%)$ & $59(78.7 \%)$ & $215(61.4 \%)$ & \\
\hline \multirow[t]{3}{*}{ Job requirements } & Satisfied & $84(19.8 \%)$ & $11(14.7 \%)$ & $73(20.9 \%)$ & $\mathrm{p}<0.001$ \\
\hline & In the middle & $67(15.8 \%)$ & $5(6.7 \%)$ & $62(17.7 \%)$ & \\
\hline & Unsatisfied & $215(50.6 \%)$ & $43(57.3 \%)$ & $172(49.1 \%)$ & \\
\hline \multirow[t]{3}{*}{$\begin{array}{l}\text { Work organization } \\
\text { policies }\end{array}$} & Satisfied & $147(34.6 \%)$ & $30(40.0 \%)$ & $117(33.4 \%)$ & $\mathrm{p}<0.001$ \\
\hline & In the middle & $63(14.8 \%)$ & $2(2.7 \%)$ & $61(17.4 \%)$ & \\
\hline & Unsatisfied & $195(45.9 \%)$ & $38(50.7 \%)$ & $157(44.9 \%)$ & \\
\hline \multirow[t]{3}{*}{$\begin{array}{l}\text { Interaction with } \\
\text { physicians }\end{array}$} & Satisfied & $147(34.6 \%)$ & $24(32.0 \%)$ & $123(35.1 \%)$ & $\mathrm{p}<0.01$ \\
\hline & In the middle & $83(19.5 \%)$ & $13(17.3 \%)$ & $70(20.0 \%)$ & \\
\hline & Unsatisfied & $85(20.0 \%)$ & $14(18.7 \%)$ & $71(20.3 \%)$ & \\
\hline \multirow[t]{2}{*}{ Interaction with nurses } & Satisfied & $268(63.1 \%)$ & $49(65.3 \%)$ & $219(62.6 \%)$ & n.s. \\
\hline & In the middle & $72(16.9 \%)$ & $12(16.0 \%)$ & $60(17.1 \%)$ & \\
\hline
\end{tabular}

supply nurse coordinators with tools which make it possible for them to monitor the interpersonal work climate. ITL the hospital is mostly influenced by the characteristics of work duties and by organizational policies. This result is also important for emphasizing the need to pay attention to managing policies set by human resource management direction. Finally, ITL the nursing profession is influenced, besides organizational policies, by professional status and by pay. The latter aspect confirms what has been shown by previous research $[21,39,41]$.

\subsection{Limitations}

A first limitation of the present study concerns the fact that analyses shown in Tables 10 to $\mathbf{1 2}$ explain a variance percentage relative to the three kinds of ITL between $38 \%$ and $44 \%$. Even if these data are superior to those obtained by $[21,49,90]$, respectively $35 \%, 31 \%$ and $34 \%$, it is important to note that more than $50 \%$ of variance could not be explained. Such data show that other important predictors of ITL should be taken into account in further research. Moreover, there might exist other factors of JS not taken into account in the questionnaire employed but detectable by means of other questionnaires or by explorative research based on a qualitative approach [25].

A second limitation lies in the fact that a self-reported questionnaire was used to collect data for this study, leading to possible response bias from each responder [99].

A third limitation concerns the exclusive presence of critical care and intensive care units. The choice of focusing on such units has been taken both in relation to previous studies that had detected a higher ITL in such units $[6,12,14]$ and by the fact that there are no data available in Italy in relation to these specific units. It would however be interesting to compare this results with other data collected in other units of the same organizations, above all to understand if critical and intensive care personnel is different. A research programme 
Table 10. Logistic regression model on nurses' ITL the unit.

\begin{tabular}{|c|c|c|c|}
\hline \multirow{2}{*}{ Predictor } & \multicolumn{3}{|c|}{ ITL the unit $(\mathrm{N}=409)$} \\
\hline & O.R. & 95\% C.I. & p-value \\
\hline \multicolumn{4}{|c|}{ JS: Interaction with physicians } \\
\hline Unsatisfied* & 1 & & \\
\hline Satisfied & 16.37 & $2.38-96.86$ & $\mathrm{p}<0.01$ \\
\hline In the middle & 1.23 & $0.68-1.71$ & $\mathrm{p}=0.22$ \\
\hline \multicolumn{4}{|l|}{ JS: Interaction with nurses } \\
\hline Unsatisfied $^{*}$ & 1 & & \\
\hline Satisfied & 13.42 & $1.17-153.23$ & $\mathrm{p}<0.01$ \\
\hline In the middle & 1.39 & $0.45-3.19$ & $\mathrm{p}=0.07$ \\
\hline \multicolumn{4}{|l|}{ Work experience } \\
\hline$\leq 5^{*}$ & 1 & & \\
\hline $6-10$ & 1.32 & $0.19-3.61$ & $\mathrm{p}=0.19$ \\
\hline $11-20$ & 2.89 & $0.56-7.02$ & $\mathrm{p}=0.08$ \\
\hline$\geq 20$ & 11.1 & $1.15-69.8$ & $\mathrm{p}<0.01$ \\
\hline \multicolumn{4}{|l|}{ Unit } \\
\hline Emergency* & 1 & & \\
\hline Cardiology & 1.05 & $0.49-1.99$ & $\mathrm{p}=0.88$ \\
\hline Medicine & 6.14 & $1.04-32.61$ & $\mathrm{p}<0.05$ \\
\hline Obstetrics and neonatal & 9.26 & $1.14-45.96$ & $\mathrm{p}<0.01$ \\
\hline Paediatrics & 3.96 & $0.84-7.56$ & $\mathrm{p}=0.08$ \\
\hline Surgery & 1.69 & $0.30-3.76$ & $\mathrm{p}=0.12$ \\
\hline
\end{tabular}

Hosmer-Lemeshow goodness-of-fit test $\left(\chi^{2}=1.37, \mathrm{p}=0.995\right)$; Nagelkerke $\mathrm{R}^{2}=0.41 ;$; Reference point.

Table 11. Logistic regression model on nurses' ITL the hospital.

\begin{tabular}{cccc}
\hline \multirow{2}{*}{ Predictor } & \multicolumn{3}{c}{ ITL the hospital $(\mathrm{N}=361)$} \\
\cline { 2 - 4 } & O.R. & $95 \%$ C.I. & $\mathrm{p}$-value \\
\hline JS: Job requirements & & & \\
Unsatisfied $^{*}$ & 1 & & \\
Satisfied & 11.79 & $2.91-45.02$ & $\mathrm{p}<0.01$ \\
In the middle & 1.87 & $0.68-4.57$ & $\mathrm{p}=0.22$ \\
JS: Work organization policies & & & \\
Unsatisfied & & & \\
Satisfied & 1 & & \\
In the middle & 12.36 & $2.18-57.45$ & $\mathrm{p}<0.01$ \\
Hospital & 1.76 & $0.94-2.73$ & $\mathrm{p}=0.16$ \\
Private & & & \\
Public & 1 & & \\
Educational level & 8.79 & $2.46-32.24$ & $\mathrm{p}<0.05$ \\
Degree/Master/Specialization & & & \\
Diploma & 1 & & \\
Work experience & 6.83 & $0.62-45.63$ & $\mathrm{p}<0.05$ \\
$\leq 5^{*}$ & & & \\
6 - 10 & 1 & & \\
$11-20$ & 1.75 & $0.87-3.23$ & $\mathrm{p}=0.17$ \\
$\geq 20$ & 6.12 & $0.71-23.51$ & $\mathrm{p}=0.07$ \\
& 12.14 & $2.13-81.41$ & $\mathrm{p}<0.01$ \\
\hline
\end{tabular}

Hosmer-Lemeshow goodness-of-fit test $\left(\chi^{2}=1.32, \mathrm{p}=0.991\right)$; Nagelkerke $\mathrm{R}^{2}=0.38$; "Reference point.
Table 12. Logistic regression model on nurses' ITL the nursing profession $(\mathrm{N}=425)$.

\begin{tabular}{|c|c|c|c|}
\hline \multirow{2}{*}{ Predictor } & \multicolumn{3}{|c|}{ ITL the nursing profession } \\
\hline & O.R. & 95\% C.I. & $\mathrm{p}$-value \\
\hline \multicolumn{4}{|c|}{ JS: Professional status } \\
\hline Unsatisfied $^{*}$ & 1 & & \\
\hline Satisfied & 9.29 & $2.11-61.33$ & $\mathrm{p}<0.05$ \\
\hline In the middle & 1.16 & $0.38-2.42$ & $\mathrm{p}=0.36$ \\
\hline \multicolumn{4}{|l|}{ JS: Pay } \\
\hline Unsatisfied $^{*}$ & 1 & & \\
\hline Satisfied & 10.78 & $1.17-99.20$ & $\mathrm{p}<0.05$ \\
\hline In the middle & 1.57 & $0.62-2.51$ & $\mathrm{p}=0.27$ \\
\hline \multicolumn{4}{|c|}{ JS: Work organization policies } \\
\hline Unsatisfied $^{*}$ & 1 & & \\
\hline Satisfied & 12.79 & $1.24-106.76$ & $\mathrm{p}<0.01$ \\
\hline In the middle & 1.33 & $0.49-3.21$ & $\mathrm{p}=0.12$ \\
\hline \multicolumn{4}{|l|}{ Age } \\
\hline$\leq 29^{*}$ & 1 & & \\
\hline $30-39$ & 1.74 & $0.49-3.96$ & $\mathrm{p}=0.19$ \\
\hline $40-49$ & 7.33 & $0.76-68.88$ & $\mathrm{p}<0.05$ \\
\hline$\geq 50$ & 13.41 & $1.09-108.92$ & $\mathrm{p}<0.01$ \\
\hline \multicolumn{4}{|l|}{ Work schedule } \\
\hline Full-time ${ }^{*}$ & 1 & & \\
\hline Part-time & 0.25 & $0.112-0.892$ & $\mathrm{p}<0.05$ \\
\hline
\end{tabular}

Hosmer-Lemeshow goodness-of-fit test $\left(\chi^{2}=1.41, \mathrm{p}=0.997\right)$; Nagelkerke $\mathrm{R}^{2}=0.44 ;{ }^{*}$ Reference point.

addressed at that goal is due in spring 2013.

A fourth limitation lies in the fact that the data obtained might not be representative of the national ones, since both hospitals investigated are in northern Italy, an area where it is more likely to find a way of re-collocating (in another hospital or another profession) compared to other Italian regions.

Lastly, a fifth limitation concerns the fact that it was not possible to verify whether ITL is linked to actually leaving (the unit, the hospital and the nursing profession) by means of a longitudinal study. To this purpose it would be worth suggesting - in the Italian context - a study similar to the one conducted by [6], based on interviews with those who have already left their profession.

\subsection{Implications for Nursing Management}

Often, hospitals attempt to solve their turnover problem by increasing recruitment efforts, but this response does not address the problem. It is far less expensive and disruptive to keep on nurses than to replace them. Once the causes of nurse turnover have been clearly identified, effective strategies can be implemented to better orient, 
educate, satisfy, motivate, and keep on quality nursing staff [6]. In light of this remark some interventions are suggested.

In general terms, nurse managers should regularly monitor ITL the unit, the hospital, and the nursing profession in their organizations (e.g. with survey questionnaires or as a part of developmental discussions) because a period of consideration (even two-three years) has been detected before nurses make the final decision to leave $[26,27]$. In addition, according to [100], interviews with nurses leaving the hospital or the nursing profession should also be performed to find out why they have made the final decision to leave: such information would be useful in limiting the number of nurses from leaving in the future. It would also be relevant to plan actions aimed at favouring organizational socialization in order to foster efficacy of new personnel's integration, particularly in units showing a higher turnover.

Other interventions could focus on the variables that have proved to be predictors of ITL.

In order to limit ITL the unit, the quality of the relationship with physicians and colleagues should be improved, favouring, for instance, meeting opportunities, even informal, for the unit staff, or offering people in charge (head physicians and nurse coordinators) training or counselling programmes aimed at acquiring better competence in group management. It would also be important to offer the possibility to change units, even remaining within critical care and intensive care units, to nurses who show a desire to do so, in order to reduce the likelihood of the development of ITL the hospital or the nursing profession.

To reduce ITL the hospital it would be important to focus on working demands and on organizational policies. In particular, after examining our research results, de-bureaucratizing activities and better managing shifts and schedules. As for the latter, the solution suggested by [6] could be considered: giving nurses wishing to the possibility to chose the weekend package, catching up hours on other weekdays. This would allow other nurses to work fewer weekends. Moreover, in order to limit ITL the hospital, competence of graduated nurses should be acknowledged by verifying that attributions of responsibilities and career promotions are based truly on merit. In order to lessen ITL the nursing profession, [6]'s advice relative to autonomy and acknowledgement could be followed: staff nurses are encouraged to participate in nursing committees, assume leadership roles, and become decision-makers. Moreover, the organization should reconsider its performance evaluation system in order to recognize clinical excellence in nursing. As for pay, on the other hand, commitment should be undertaken by the IPASVI Federation to negotiate a National collective agreement adequate to the professionalism shown by nurses working in Italian hospitals.

\section{REFERENCES}

[1] Flinkman, M., Leino-Kilpi, H. and Salanterä, S. (2010) Nurses' intention to leave the profession: Integrative review. Journal of Advanced Nursing, 66, 1422-1434. doi:10.1111/j.1365-2648.2010.05322.x

[2] Simoens, S., Villeneuve, M. and Hurst, J. (2005) Tackling nurse shortages in OECD Countries. OECD Health Working Papers, 19.

http://www.oecd.org/health/healthpoliciesanddata/345713 65.pdf

[3] World Health Organization (2008) The world health report 2008-Now more than ever. http://www.who.int/whr/2008/whr08 en.pdf

[4] Oulton, J.A. (2006) The global nursing shortage: An overview of Issues and Actions. Policy Politics Nursing Practice, 7, 34S-39S. doi:10.1177/1527154406293968

[5] Dubois, C.-A., McKee, M. and Rechel, B. (2006) Critical challenges facing the health care workforce in Europe. In: Rechel, B., Dubois, C.-A. and McKee, M., Eds, World Health Organization, on Behalf of the European Observatory on Heath Systems and Policies, The Cromwell Press, Trowbridge, 1-18.

http://www.euro.who.int/ data/assets/pdf file/0008/914 75/E89156.pdf

[6] Strachota, E., Normandin, P., O’Brien, N., Clary, M. and Krukow, B. (2003) Reasons registered nurses leave or change employment status. Journal of Nursing Administration, 33, 111-117.

http://journals.lww.com/jonajournal/Fulltext/2003/02000/ Reasons_Registered_Nurses_Leave_or_Change.8.aspx

[7] Clarke, S. and Aiken, L. (2003) Failure to rescue: Needless deaths are prime examples of the need for more nurses at the bedside. American Journal of Nursing, 103, 4247.

http://www.uic.edu/depts/oce/OCEweb/04FA/ClarkeAike n.pdf

[8] Aiken, L.H., Clarke, S.P., Sloane, D.M., Sochalski, J.A. and Silber, J.H. (2002) Hospital nurse staffing and patient mortality, nurse burnout, and job dissatisfaction. Journal of the American Medical Association, 288, 1987-1993. doi:10.1001/jama.288.16.1987.

[9] Wagner, C.M. (2010) Predicting nursing turnover with catastrophe theory. Journal of Advanced Nursing, 66, 20712084. doi:10.1111/j.1365-2648.2010.05388.x

[10] Rivers, P.A., Tsai, K.-L. and Munchus, G. (2005) The financial impacts of the nursing shortage. Journal of Health Care Finance, 31, 52-64.

http://content.ebscohost.com/pdf9/pdf/2005/HLT/01Mar0 5/16946431.pdf

[11] Jones, C.B. (2005) The costs of nurse turnover, part 2: Application of the nursing turnover cost calculation methodology. Journal of Nursing Administration, 35, 41-49. http://journals.lww.com/jonajournal/Abstract/2005/01000 /The Costs_of_Nurse Turnover,_Part_2 Application.1 4.aspx 
[12] Stone, P.W., Larson, E.L., Mooney-Kane, C., Smolowitz, J., Lin, S.X. and Dick, A. (2009) Organizational climate and intensive care unit nurses' intention to leave. Journal of Nursing Administration, 39, S37-S42. doi:10.1097/01.CCM.0000218411.53557.29

[13] van Dam, K., Meewis, M. and van der Heijden, B.I. (2012) Securing intensive care: towards a better understanding of intensive care nurses' perceived work pressure and turnover intention. Journal of Advanced Nursing, in press. doi:10.1111/j.1365-2648.2012.05981.x.

[14] Odom, J. (2000) Nursing shortage: Impending doom or challenging opportunity. Journal Perianesthesia Nursing, 15, 348-349. doi:10.1053/jpan.2000.18206

[15] Bertinato, L., Glinos, I.A., Boscolo, E. and Ciato, L. (2009) Oversupplying doctors but seeking carers: Italy's demographic challenges and health professional mobility. Health Professional Mobility and Health Systems Observatory Studies, 23, 243-262.

http://www.sfes.info/IMG/pdf/Health professional mobil ity and Health systems.pdf\#page $=276$

[16] Chaloff, J. (2008) Mismatches in the formal sector, expansion of the informal sector: Immigration of health professionals to Italy. Organisation for Economic Co-operation and Development Health Working Papers, Paris, 34. http://www.oecd.org/italy/41431698.pdf

[17] Ghizzoni, A.M. and Avenati, L. (2010) La professione infermieristica, una scelta che paga. L'infermiere, 1, 18-23.

[18] Regione Emilia Romagna (2011) Dinamiche del personale infermieristico nelle Aziende sanitarie. Permanenza in servizio e mobilità in uscita. http://asr.regione.emilia-romagna.it/wcm/asr/collana dos sier/doss $100 . \mathrm{htm}$

[19] Wismar, M., Maier, C.B., Glinos, I.A., Dussault, G. and Figueras, J. (2011) Health professional mobility and health systems. Evidence from 17 European countries. http://www.euro.who.int/_ data/assets/pdf_file/0017/152 324/e95812.pdf

[20] Sourdif, J. (2004) Predictors of nurses' intent to stay at work in a university health center. Nursing and Health Sciences, 6, 59-68. doi:10.1111/j.1442-2018.2003.00174.x

[21] Tourangeau, A.E. and Cranley, L.A. (2006) Nurse intention to remain employed: Understanding and strengthening determinants. Journal of Advanced Nursing, 55, 497509. doi:10.1111/j.1365-2648.2006.03934.x

[22] Beecroft, P.C., Dorey, F. and Wenten, M. (2008) Turnover intention in new graduate nurses: A multivariate analysis. Journal of Advanced Nursing, 62, 41-52. doi:10.1111/j.1365-2648.2007.04570.x

[23] Galletta, M., Portoghese, I., Penna, M.P., Battistelli, A. and Saiani, L. (2011) Turnover intention among Italian nurses: The moderating roles of supervisor support and organizational support. Nursing \& Health Sciences, 13, 184-191. doi:10.1111/j.1442-2018.2011.00596.x

[24] Krausz, M., Koslowsky, M., Shalom, N. and Elyakim, N. (1995) Predictors of intentions to leave the ward, the hospital, and the nursing profession: An longitudinal study. Journal of Organizational Behaviour, 16, 277-288. doi:10.1002/job.4030160308
[25] Morrell, K. (2005) Towards a typology of nursing turnover: The role of shocks in nurses' decisions to leave. Journal of Advanced Nursing, 49, 315-322. doi:10.1111/j.1365-2648.2004.03290.x

[26] Hasselhorn, H.-M., Muller, B.H., Tackenberg, P., Wittenberg, J., Kuemmerling, A., Simon, M. and the NEXT Study Group (2005) Nursing in Europe: Intention to leave the nursing profession. In: Hasselhorn, H.-M., Muller, B.H. and Tackenberg, P., Eds., NEXT Scientific Report, Elanders Gotab AB, Vallingby, 17-24.

[27] Lum, L., Kervin, J., Clark, K., Reid, F. and Sirola, W. (1998) Explaining nursing turnover intent: Job satisfaction, pay satisfaction, on organizational commitment? Journal of Organizational Behaviour, 19, 305-320. doi:10.1002/(SICI)1099-1379(199805)

[28] Tham, P. (2007) Why are they leaving? Factors affecting intention to leave among social workers in child welfare. British Journal of Social Work, 37, 1225-1246. doi:10.1093/bjsw/bcl054

[29] McCarthy, G., Tyrrel, M.P. and Lehane, E. (2007) Intention to "leave" or "stay" in nursing. Journal of Nursing Management, 15, 248-255. doi:10.1111/j.1365-2834.2007.00648.x

[30] Shields, M.A. and Ward, M. (2001) Improving nurse retention in the National Health Service in England: The impact of job satisfaction on intention to quit. Journal of Health Economics, 20, 677-701. doi:10.1016/S0167-6296(01)00092-3

[31] Borda, B. and Norman, I. (1997) Factors influencing turnover and absence of nurses: A research review. International Journal of Nursing Studies, 34, 385-394. doi:10.1016/S0020-7489(97)00031-X,

[32] Cowin, L. (2002) The effects of nurses' job satisfaction on retention: An Australian perspective. Journal of Nursing Administration, 32, 283-291. http://journals.lww.com/jonajournal/Abstract/2002/05000 /The_Effects_of_Nurses_Job_Satisfaction_on.8.aspx

[33] Destrebecq, A., Terzoni, S., Colosso, C., Neri, L. and Brambilla, G. (2009) Intention to leave nursing in a major Milan hospital: Current situation and future perspectives. La medicina del Lavoro, 100, 109-119.

[34] Hsiao, Y. and Lu, M. (1996) A study of organizational commitment, organizational retention and professional retention of clinical nurses? Nursing Research, 4, 137150.

[35] Ingersoll, G.L., Olsan, T., Drew-Cates, J., DeVinney, B.C. and Davies, J. (2002) Nurses' job satisfaction, organizational commitment and career intent. Journal of Nursing Administration, 32, 250-263.

http://journals.lww.com/jonajournal/Abstract/2002/05000 Nurses Job Satisfaction, Organizational.5.aspx

[36] Price, J.L. (2004) The development of a causal model of voluntary turnover. In: Griffeth and Hom, P., Eds, Innovative Theory and Empirical Research on Employee Turnover, Information Age Publishing, Charlotte, 3-32.

[37] Barron, D. and West, A.E. (2005) Leaving nursing: An event-history analysis of nurses' career. Journal of Health Services Research \& Policy, 10, 105-157.

[38] Lacey, L.M. (2003) Called into question: What nurses 
want? Nursing Management, 34, 25-26.

[39] Santos, S.R. and Cox, K. (2000) Workplace adjustment and intergenerational differences between nurses, boomers and Xers. Nursing Economics, 18, 7-13.

[40] Roberts, B.J., Jones, C. and Lynn, M. (2004) Job satisfaction of new baccalaureate nurses. Journal of Nursing Administration, 34, 428-435.

http://journals.lww.com/jonajournal/Fulltext/2004/09000/ Job Satisfaction of New Baccalaureate Nurses.9.aspx

[41] Larrabee, J.H., Janney, M.A., Ostrow, C.L., Withrow, M.L., Hobbs, G.R. and Burant, C. (2003) Predicting registered nurse job satisfaction and intent to leave. Journal of Nursing Administration, 33, 271-283.

http://journals.lww.com/jonajournal/Fulltext/2003/05000/ Predicting_Registered_Nurse_Job_Satisfaction_and.3.a s px

[42] Flinkman, M., Laine, M., Leino-Kilpi, H., Hasselohorn, H.-M. and Salanterä, S. (2008) Explaining young registred Finnish nurses' intention to leave the profession: A questionnaire survey. International Journal of Nursing Study, 45, 727-739. doi:10.1016/j.ijnurstu.2006.12.006

[43] Joshua-Amadi, M. (2002) Recruitment and retention: A study in motivation. Nursing Management, 9, 17-21. http://nursingmanagement.rcnpublishing.co.uk/archive/art icle-recruitment-and-retention-a-study-in-motivation

[44] Blegen, M.A. (1993) Nurses' job satisfaction: A metaanalysis of related variables. Nursing Research, 42, 36-41. doi:10.1097/00006199-199301000-00007

[45] Hu, J., Herrick, C. and Allard, H.K. (2004) Managing the multigenerational nursing team. The Health Care Manager, 23, 334-340.

http://journals.lww.com/healthcaremanagerjournal/Abstra ct/2004/10000/Managing the Multigenerational_Nursing Team.8.aspx

[46] Kuokkanen, L., Leino-Kilpi, H. and Katajisto, J. (2003) Nurse empowerment, job-related satisfaction, and organizational commitment. Journal of Nursing Care Quality, 18, 184-193.

[47] Laine, M. (2005) Hoitajana huomennakin. Hoitajien tyopaikkaan ja ammattiin sitoutuminen/Organizational and professional commitment of nurses. Finnish Institute of Occupational Health. University of Turku, Scripta lingua Finnica edita 0082-6995.

[48] Chan, E. and Morrison, P. (2000) Factors influencing the retention and turnover intentions of registered nurses in a Singapore hospital. Nursing and Health Sciences, 2, 113121. doi:10.1046/j.1442-2018.2000.00046.x

[49] Shader, K., Broome, M.E., Broome, C.D., West, M.E. and Nash, M. (2001) Factors influencing satisfaction and anticipated turnover for nurses in an academic medical center. Journal of Nursing Administration, 31, 210-217. http://journals.lww.com/jonajournal/Fulltext/2001/04000/ Factors_Influencing_Satisfaction_and_Anticipated.10. as px

[50] Takase, M., Maude, P. and Manias, E. (2006) The impact of role discrepancy on nurses' intention to quit their jobs. Journal of Clinical Nursing, 15, 1071-1080. doi:10.1111/j.1365-2702.2005.01508.x

[51] Ito, H., Eisen, S.V., Sederer, L.I., Yamada, O. and Tachi- mori, H. (2001) Factors affecting psychiatric nurses' intention to leave their current job. Psychiatric Services, 52, 232-234. doi:10.1176/appi.ps.52.2.232

[52] Acker, G.M. (2004) The effect of organizational conditions (role conflict, role ambiguity, opportunities for professional development, and social support) on job satisfaction and intention to leave among social workers in mental health care. Community Mental Health Journal, 40, 65-73.

doi:10.1023/B:COMH.0000015218.12111.26

[53] Adams, A. and Bond, S. (2000) Hospital nurses' job satisfaction, individual and organizational characteristics. Journal of Advanced Nursing, 32, 536-543. doi:10.1046/j.1365-2648.2000.01513.x.

[54] Hemingway, M.A. and Smith, C.S. (1999) Organizational climate and occupational stressors as predictors of withdrawal behaviours and injuries in nurse. Journal of Occupational and Organizational Psychology, 72, 285-299. doi:10.1348/096317999166680

[55] AbuAlRub, R.F. and Al-Zaru, I.M. (2008) Job stress, recognition, job performance and intention to stay at work among Jordanian hospital nurses. The Journal of Nursing Management, 16, 227-236. doi:10.1111/j.1365-2834.2007.00810.x

[56] Barnett, R.C., Gareis, K.C. and Carr, P.L. (2005) Career satisfaction and retention of women physicians who work reduced hours. Journal of Women's Health, 14, 146-153. doi:10.1089/jwh.2005.14.146.

[57] Camerino, D., Conway, P.M., van der Heijden, B.I.J.M., Estryn-Béhar, M., Costa, G. and Hasselhorn, H.-M. (2008) Age-dependent relationship between work ability, thinking of quitting the job, and actual leaving among Italian nurse: A longitudinal study. International Journal of Nursing Studies, 45, 1645-1659. doi:10.1016/j.ijnurstu.2008.03.002

[58] Estryn-Be'har, Van der Heijden, B.I., Oginska, H., Camerino, D., Le Nèzet, O., Conway, P.M., Fry, C., Hasselhorn, H.-M. and NEXT Study Group (2007) The impact of social work environment, teamwork characteristics, burnout, and personal factors upon intent to leave among European nurse. Medical Care, 45, 939-950. doi:10.1097/MLR.0b013e31806728d8

[59] Hasselhorn, H.-M., Muller, B.H. and Tackenberg, P. (2005) NEXT Scientific Report.

http://www.econbiz.de/archiv1/2008/53602_nurses_work europe.pdf

[60] Hasselhorn, H.M., Tackenberg, P. and Müller, B.H. (2003) Working conditions and intent to leave the profession among nursing staff in Europe. SALTSA_-Joint Programme for Working Life Research in Europe Report No 7, 7. http://nile.lub.lu.se/arbarch/saltsa/2003/wlr2003 07.pdf

[61] Simon, M., Kummerling, A., Hasselhorn, H.M. and NEXT Study Group (2004) Work-home conflict in the European nursing profession. International Journal of Occupational Environmental Health, 10, 384-391.

[62] Balloch, S., Pahl, J. and McLean, J. (1998) Working in the social services: Job satisfaction, stress and violence. British Journal of Social Work, 28, 329-350. http://bjsw.oxfordjournals.org/content/28/3/329.short 
[63] Zeytinoglu, I.U., Denton, M., Davies, S., Baumann, A., Blythe, J. and Boos, L. (2006) Retaining nurses in their employing hospitals and in the profession: Effects of job preference, unpaid overtime, importance of earnings and stress. Health Policy, 79, 57-72.

doi:10.1016/j.healthpol.2005.12.004

[64] Spector, P.E. (1997) Job satisfaction. Sage Publications, Thousand Oaks.

[65] Weiss, H.M. (2002) Deconstructing job satisfaction: Separating evaluations, beliefs and affective experiences. $H u$ man Resource Management Review, 12, 173-194. doi:10.1016/S1053-4822(02)00045-1

[66] Williams, J. (2004) Job satisfaction and organizational commitment, a Sloan Work and Family Encyclopedia entry.

http://wfnetwork.bc.edu/encyclopedia_entry.php?id=244 \&area $=$ academics

[67] Cortese, C.G. (2007) Job satisfaction of Italian nurses: An exploratory study. Journal of Nursing Management, 15, 303-312. doi:10.1111/j.1365-2834.2007.00694.x

[68] Aiken, L.H., Clarke, S.P. and Sloane, D.M. (2000) Hospital restructuring: does it adversely affect care and outcomes? The Journal of Nursing Administration, 30, 457465.

http://journals.lww.com/jonajournal/Abstract/2000/10000 /Hospital_Restructuring_Does_It_Adversely_Affect.3.a $\underline{\operatorname{spx}}$

[69] Aiken, L.H., Smith, H.L. and Lake, E.T. (1994) Lower medicare mortality among a set of hospitals known for good nursing care. Medical care, 32, 771-787. http://www.jstor.org/discover/10.2307/3766652?uid=373 8296\&uid=2\&uid=4\&sid=21101282535247

[70] Hellman, C.M. (1997) Job satisfaction and the intent to leave. Journal of Social Psychology, 137, 677-689. doi:10.1080/00224549709595491

[71] Kramer, M. and Schmalenberg, C. (1991) Job satisfaction and retention. Insight for the 90's. Nursing, 21, 50-55.

[72] Ruggiero, J.S. (2005) Health, work variables, and job satisfaction among nurses. Journal of Nursing Administration, 35, 254-263.

http://journals.lww.com/jonajournal/Fulltext/2005/05000/ Health, Work Variables, and Job Satisfaction Among. 9.aspx

[73] Sochalski, J. (2001) Nursing's valued resources: Critical issues in economics and nursing care. The Canadian Journal of Nursing Research, 33, 11-18.

[74] Tzeng, H.M. (2002) Satisfying nurses on job factors they care about. A Taiwanese perspective. Journal of Nursing Administration, 32, 306-309.

http://journals.lww.com/jonajournal/Fulltext/2002/06000/ Satisfying_Nurses_on_Job_Factors They_Care_About.5. $\underline{\operatorname{aspx}}$

[75] Bowling, N.A., Eschleman, K.J. and Wang, Q. (2010) A meta-analytic examination of the relationship between job satisfaction and subjective well-being. Journal of Occupational and Organizational Psychology, 83, 915-934. doi:10.1348/096317909X478557

[76] Jenkins, J.M. (1993) Self monitoring and turnover: The impact of personality on intent to leave. Journal of Organizational Behaviour, 14, 83-91.

doi:10.1002/job.4030140108

[77] Stamps, P.L. (1997) Nurses and work satisfaction: An index for measurement. Healt Administration Press, Chicago.

[78] Adams, A., Bond, S. and Hale, C.A. (1998) Nursing organizational practice and its relationship with other features of ward organization and job satisfaction. Journal of $\mathrm{Ad}$ vanced Nursing, 27, 1212-1222. doi:10.1046/j.1365-2648.1998.00657.x

[79] Irvine, D.M. and Evans, M.G. (1995) Job-satisfaction and turnover among nurses - Integrating research findings across studies. Nursing Research, 44, 246-253. doi:10.1097/00006199-199507000-00010

[80] Kangas, S., Kee, C.C. and McKee-Waddle, R. (1999) Organizational factors, nurses' job satisfaction, and patient satisfaction with nursing care. Journal of Nursing Administration, 29, 32-42.

http://journals.lww.com/jonajournal/Fulltext/1999/01000/O rganizational Factors, Nurses Job Satisfaction,.6.asp x

[81] Mäkinen, A., Kivimäki, M., Elovainio, M., Virtanen, M. and Bond, S. (2003) Organization of nursing care as a determinant of job satisfaction among hospital nurses. Journal of Nursing Management, 11, 299-306. doi:10.1046/j.1365-2834.2003.00399.x

[82] Mills, A. and Blaesing, S. (2000) A lesson from the last nursing shortage. Journal of Nursing Administration, 30, 309-315.

http://journals.lww.com/jonajournal/Fulltext/2000/06000/A Lesson from the Last Nursing Shortage The.9.aspx

[83] Tovey, E.J. and Adams, A.E. (1999) The changing nature of nurses' job satisfaction: An exploration of sources of satisfaction in the 1990s. Journal of Advanced Nursing, 30, 150-158. doi:10.1046/j.1365-2648.1999.01059.x

[84] Cavanagh, S.J. (1992) Job satisfaction of nursing staff working in hospitals. Journal of Advanced Nursing, 17, 704-711. doi:10.1111/j.1365-2648.1992.tb01968.x

[85] Best, M.F. and Thurston, N.E. (2004) Measuring nursing job satisfaction. Journal of Nurcing Administration, 34, 283-290.

http://journals.lww.com/jonajournal/Abstract/2004/06000 /Measuring_Nurse_Job_Satisfaction.7.aspx

[86] Ma, C.C., Samuels, M.E. and Alexander, J.W. (2003) Factors that influence nurses' job satisfaction. Journal of Nursing Administration, 33, 293-299.

http://journals.lww.com/jonajournal/Abstract/2003/05000 Factors That Influence Nurses Job_Satisfaction.5.aspx

[87] Cortese, C.G., Colombo, L. and Ghislieri, C. (2010) Determinants of nurses' job satisfaction: The role of workfamily conflict, job demand, emotional charge and social support. Journal of Nursing Management, 18, 35-43. doi:10.1111/j.1365-2834.2009.01064.x

[88] Ganster, D.C. and Schaubroeck, J. (1991) Work stress and employee health. Journal of Management, 17, 235271. doi:10.1177/014920639101700202

[89] Netemeyer, R.G., McMurrian, R. and Boles, J.S. (1996) Development and validation of work-family conflict and 
family-work conflict scales. Journal of Applied Psychology, 81, 400-410. doi:10.1037/0021-9010.81.4.400

[90] Chan, M.F., Luk, A.L., Leong, S.M., Yeung, S.M. and Van, I.K. (2008) Factors influencing Macao nurses' intention to leave current employment. Journal of Clinical Nursing, 18, 893-901. doi:10.1111/j.1365-2702.2008.02463.x

[91] Hosmer, D. W. and Lemeshow, S. (2000) Applied logistic regression. Wiley, New York.

[92] Camerino, D., Conway, P.M. and Lusignani, M. (2005) Condizioni di lavoro e intenzione di cambiare: Risultati dello studio europeo NEXT in Italia. Giornale Italiano di Scienze Infermieristiche, 1, 12-25. http://air.unimi.it/handle/2434/5427

[93] Camerino, D., Lusignani, M., Conway, P., Bertazzi, P.A. and Gruppo NEXT (2004) L'intenzione di lasciare la professione infermieristica. La Medicina del Lavoro, 95, 354-364.

http://www.lamedicinadellavoro.it/summary/2004/vol 95 05/02_vol 95_05.pdf

[94] Ferrari, F. (2010) The nurse job satisfaction. Comparison between ideal job and organizational reality: A preliminary study. Munich Personal RePEc Archive Paper. http://mpra.ub.uni-muenchen.de/24798/

[95] Tabolli, S., Ianni, A., Renzi, C., Di Pietro, C. and Puddu, P. (2006) Job satisfaction, burnout and stress amongst nursing staff: A survey in two hospitals in Rome. Gior- nale Italiano di Medicina del Lavoro ed Ergonomia, 28, 49-52. http://gimle.fsm.it/28/1s psi/07.pdf

[96] Steel, R.P. (2002) Turnover theory at the empirical interface: Problem of fit and function. Academic of Management Review, 27, 346-360.

http://www.jstor.org/discover/10.2307/4134383?uid=373 $\underline{8296 \& \text { uid }=2 \& \text { uid }=4 \& \text { sid }=21101293632717}$

[97] Tai, T.W., Bame, S.I. and Robinson, C.D. (1998) Review of nursing turnover research, 1977-1996. Social Science \& Medicine, 47, 1905-1924. doi:10.1016/S0277-9536(98)00333-5

[98] Wilson, B., Squires, M., Widger, K., Cranley, L. and Tourangeau, A. (2008) Job satisfaction among a multigenerational nursing workforce. Journal of Nursing Management, 16, 716-723. doi:10.1111/j.1365-2834.2008.00874.x

[99] Polit, D.F. and Beck, C.T. (2004) Nursing research: Principles and methods. Lippincott Williams \& Wilkins, Philadelphia.

[100] O'Brien-Pallas, L., Griffin, P., Shamion, J., Buchan, L., Duffield, C., Hughes, F., et al. (2006) The impact of nurse turnover on patient, nurse, and system outcomes: A pilot study and focus for a multicenter international study. $\mathrm{Po}_{\mathrm{o}}$ licy, Politics, \& Nursing Practice, 7, 169-179. doi:10.1177/1527154406291936 